\title{
Employ Condensation Strategy to Study the Translation of Culture-Loaded Words in the Two Versions of The True Story of $A h Q$ and Border Town
}

\author{
Yuan He \\ School of Foreign Languages, East China University of Science and Technology, Shanghai, China \\ Email: hydaisy137@163.com
}

How to cite this paper: He, Y. (2020) Employ Condensation Strategy to Study the Translation of Culture-Loaded Words in the Two Versions of The True Story of Ah $Q$ and Border Town. Open Access Library Journal, 7: e6933.

https://doi.org/10.4236/oalib.1106933

Received: October 26, 2020

Accepted: November 15, 2020

Published: November 18, 2020

Copyright $\odot 2020$ by author(s) and Open Access Library Inc.

This work is licensed under the Creative Commons Attribution International License (CC BY 4.0).

http://creativecommons.org/licenses/by/4.0/

\section{(c) (i) Open Access}

\begin{abstract}
Culture-loaded words are of great importance in translation and play a significant role in promoting cross-cultural communication. At the same time, they also pose a great barrier to translators. Lu Xun's The True Story of $A h Q$ and Shen Congwen's Border Town are both masterpieces, and there are a large number of culture-loaded words in these two novels. Yang Xianyi and Dai Naidie as well as the famous translator Lyell have translated The True Story of $A h Q$ to English. Ching Ti and Robert Payne as well as Kinkley also have translated Border Town to English, introducing it to foreign readers. As for Chinese-English translation, Professor Wang Jianguo has put forward "condensation strategy", holding the view that this translation strategy is the only way in Chinese-English translation, which can also be applicable to the translation of culture-loaded words. The purpose of "condensation" is to eliminate ambiguity and limit readers' imagination, providing them with more accurate understanding. This thesis will employ "condensation strategy" to explore the translation of culture-loaded words in the two versions of The True Story of Ah $Q$ and Border Town.
\end{abstract}

\section{Subject Areas \\ Linguistics, Literature}

\section{Keywords}

Condensation Strategy, Culture-Loaded Words, The True Story of Ah Q, Border Town 


\section{1. 引言}

随着不同国家和地区之间的交流变得日益频繁, 翻译作为跨文化交际的 桥梁, 扮演着越来越重要的角色。对于译者来说, 翻译中最大的困难, 是不 同文化所带来的困难, 而非语言层面的翻译。美国翻译家奈达曾经说过, “对 于真正成功的翻译而言, 熟悉两种文化甚至比掌握两种语言更重要, 因为词 语只有在其作用的文化背景中才有意义” (Nida, 2001) [1]。在不同国家传承和 弘扬文化的过程中, 有些词汇承载了许多文化信息和文化内涵, 且由于文化 多元和文化差异, “源语词汇所承载的文化信息在译语中没有对应语” (包惠 南、包昂, 2004: 10) [2], 这种词汇被称之为 “文化负载词”, 如 “穿小鞋” 、 “连襟”、“阴阳”、“桃花运” 等就属于 “文化负载词”。“它是指标志某 种文化中特有事物的词, 词组和习语。这些词汇反映了特定民族在漫长的历史 进程中逐渐积累的、有别于其他民族的、独特的活动方式” (廖七一，2000） [3]。

鲁迅作为 “中国现代小说之父”, 是 20 世纪最伟大的文学家之一。《阿 $\mathrm{Q}$ 正传》作为鲁迅的代表作品, 影响非常深远。即使在今天, 我们所熟悉的 一些词汇如 “阿 $\mathrm{Q}$ 精神” 和 “精神胜利法” 就出自《阿 $\mathrm{Q}$ 正传》这部伟大的 文学作品。杨宪益、戴乃迭夫妇还有著名翻译家莱尔都曾把《阿 $\mathrm{Q}$ 正传》翻 译成英文。小说《边城》是沈从文的优秀作品之一, 小说语言不仅生动美妙, 并且地方色彩浓厚。金隄、白英以及金介甫也把这部作品翻译成了英文。

《阿 $\mathrm{Q}$ 正传》和《边城》中, 出现了很多文化负载词。关于文化负载词 翻译的策略, 历来讨论已久。王建国教授提出 “压缩策略”, 并认为这一策 略是汉英翻译的唯一策略, 同样也适用于文化负载词的翻译。本文将结合 “压 缩策略” 翻译理论, 评析《阿 $\mathrm{Q}$ 正传》和《边城》两译本中对于文化负载词 的翻译。

\section{2. 压缩策略}

王建国、何自然提出两条语用原则: “汉语语用重过程, 英语语用重结 果” (王建国、何自然, 2014：7-12) [4]。王建国认为汉语是一门过程取向的 语言, 重过程。除此之外, 汉语的过程和结果没有清晰的界限, 过程和结果 之间是无界的(unbounded)。与之相反, 英语是一门结果取向的语言, 重结果。 英语的过程和结果之间有着清晰的界限, 两者之间是有界的(bounded)。比如 汉语中的 “读懂” “听懂”, 表述中既有过程 “读” 和 “听”, 又有结果 “懂”, 但英语中往往只取 “懂” (understand)这个结果, 过程会被省去。汉语重过程, 英语重结果, 这两种不同思维方式的语言不可避免的会影响到译者。王建国 比较了杨宪益主译的《红楼梦》版本和霍克斯的版本, 佐证了这一观点。英 语为母语的译者更重结果, 往往在汉英翻译中多推进一步。同时, 他也注意 到 “英译中会出现大量的解释现象, 即原文中看起来没有对应的内容。这种 现象往往是汉语界限意识弱造成指称不清或者原文中存在典型的文化词而引 起的” (王建国, 2019: 119) [5]。霍克斯所译的红楼梦与杨宪益主译的版本相 比, 词数更多, 原因在于霍克斯多用解释, 有很强的界限意识。

根据对汉英语言的新发现, 王建国提出了 “压缩策略”, 认为 “压缩” 
是汉英翻译的唯一策略。汉语界限弱, 英语界限强, 因此 “汉英翻译的方法 都必须具有界定功能” (王建国, 2019: 95) [5]。用通俗的话来说, “汉英翻 译策略通常是 $\mathrm{N}+1, \mathrm{~N}$ 是照着原文直译, +1 往往指代在直译的基础上往前 挪一步” (王建国, 2019: 90) [5], “往前挪一步” 具体来说, 指的是给读者 提供更加精确的翻译, 把汉语中模糊的内容翻译成相对精确且明显界限意识 的内容, 目的在于排除理解上的歧义和缩小读者的想象空间。“压缩” 的目 的在于 “使得内容的排他性更强, 精确度更高, 给人的想象空间更小” (王建 国，2019：90）[5], 排除歧义, 给读者提供更精确的理解。需要指出的一点 是, “压缩” 指得是内容或意义的压缩, 而非形式上的压缩。为了做到意义 的准确和压缩理解的空间, 译者有的时候会使用增添和加注等方法, 特别是 对文化负载词的处理, 局部译文在形式和内容上表面会表现为扩展, 但是这 种表面的扩展根本上还是发挥了压缩界限的作用, 所以仍然是压缩策略的一 种表现。汉英翻译中的 “压缩” 就是把汉语中模糊的内容转化成相对精确的 有明显界限意识的内容。压缩的过程就是 “从模糊到精确, 界限意识从含混 到清晰的转换过程” (王建国, 2019: 77) [5]。

因为杨宪益戴乃迭夫妇合作翻译了很多译本, 有学者对杨宪益夫妇的译 本是否主要受汉语母语思维影响有所怀疑, 但作为杨宪益曾经的同事黄友义, 曾经咨询过他合译本是否为自己主译, 得到的答案都是杨宪益译中文, 戴乃 迭修改润色。王建国认为戴乃迭若只是改杨宪益的译稿, 是无法改变杨宪益 作为一名母语为汉语的译者思维方式在译文中的反映的。因此王建国认为杨 宪益和戴乃迭的译本仍然反映了汉语为母语的译者的思维方式。金隄和白英 合译的《边城》也是由汉语为母语的金隄主译, 白英修改润色, 因此该译本 也可以看作反映了汉语为母语的译者的思维方式。

\section{3. 压缩策略下文化负载词翻译对比分析}

《阿 $\mathrm{Q}$ 正传》和《边城》中, 出现了很多文化负载词。本节将结合 “压 缩策略” 翻译理论, 对比分析 《阿 $\mathrm{Q}$ 正传》和《边城》两英译本中对于文化 负载词的翻译。例 1 到例 3 , 评析了《阿 $\mathrm{Q}$ 正传》两英译本中对于文化负载 词的翻译, 例 4 到例 6 , 评析了《边城》两英译本中对于文化负载词的翻译。

例 1：君子动口不动手！阿 $\mathrm{Q}$ 歪着头说。(鲁迅，2016：34）[6]

杨译: A gentleman uses his tongue but not his hands! protested Ah Q, his head on one side. (杨宪益, 2016: 35) [6]

莱尔译: His fists need never be swung, for the gentleman uses his tongue, quoted Ah Q, head cocked to one side. (Lyell, 1990: 118) [7]

“君子动口不动手” 这一文化负载词的意思是君子不会采用拳头和武力 来解决问题, 只会用口来解释和说理争辩。杨宪益的译文中, “A gentleman uses his tongue but not his hands”会让外国读者感到非常费解和困惑, 加大了他们 的想象空间。为什么君子或者绅士不使用自己的手, 用口和绅士之间到底存 在什么关联? 杨宪益的译文受到了汉语的影响, 因为汉语正如王建国所说的 那样, 是一门界限弱的语言, 表述不精确。莱尔的译文 “His fists need never be 
swung, for the gentleman uses his tongue”, 采用了压缩策略, 把 “手” 译成 了 “fists”, 意义往前推进了一步, 莱尔的译文可以直译为 “绅士只会动口, 而不是挥舞自己的拳头”, 把原文相对模糊的表述转化成精确的内容, 排除 了歧义, 给外国读者提供了准确和清晰的译文。莱尔的译文说明了英语为母 语的译者往往在汉英翻译中多推进一步, 界限意识较强。

例 2: 到进城, 已经是正午, 阿 $\mathrm{Q}$ 见自己被换进一所破衙门, 转了五六 个弯，便推在一间小屋里。(鲁迅，2016：120) [6]

杨译: It was already midday by the time they reached town, and Ah Q found himself carried to a dilapidated yamen. (杨宪益, 2016: 121) [6]

莱尔译: And by the time they entered the town with Ah Q in town, it was already high noon. He watched himself supported under the arms and escorted into a rundown yamen ${ }^{*}$ where, after five or six shifts in direction, he was finally shoved into a cell.

*The seat of a local government. (Lyell, 1990: 163) [7]

“衙门”一词属于社会文化负载词, 指古代政府机构的办公场所。杨宪 益将 “衙门” 音译为 “yamen”, 对于缺乏中国文化背景的外国读者来说, 杨宪益的译文会让他们感到困惑和不解, 不利于读者对原文的准确理解, 读 者会对 “yamen” 到底是什么展开想象。莱尔则是采用了压缩策略, 使用了 音译加注的方法, 注释 “The seat of a local government” 准确地解释了 “衙门” 的意思, 读者对原文有了更准确和清晰的理解。正如上文所说, 英语为母语 的译者在汉译英的时候, 特别是翻译文化负载词的时候, 为了减少歧义和给 读者提供更加清晰准确的翻译, 往往会加很多解释, 因为英语是一门界限感 比较强的语言。汉语界限感则相对较弱, 汉语为母语的译者容易受到汉语界 限不明的影响, 杨宪益的译文则说明了这一点。

例 3: 宣统三年九月十四日-即阿 $\mathrm{Q}$ 将搭连卖给赵白眼的这一天-三更四 点, 有一只大乌篷船到了赵府上的河埠头。(鲁迅, 2016: 88) [6]

杨译: On the fourteenth day of the ninth moon of the third year in the reign of Emperor Xuan Tong-the day on which Ah Q sold his purse to Zhao Baiyan-at midnight, after the fourth stroke of the third watch, a large boat with a big black awning came to the Zhao family's landing place. (杨宪益, 2016: 89) [6]

莱尔译: On the Fourteenth Day of the Ninth Month of the Third Year of the Xuantong Reign-in other words, on the day Ah Q sold his money pouch to Zhao Baiyan-on the Fourth Stroke of the Third Watch ${ }^{*}$, a large black-canopied boat tied up at the Zhao family wharf.

*Xuantong was the reign title of the last Qing emperor. The lunar date given here corresponds to November 4, 1911, the day Lu Xun's own hometown was "liberated." The time given is about midnight. (Lyell, 1990: 146-147) [7]

“三更四点” 属于社会文化负载词。“更” 是古时夜间计时的单位, 一 夜共分为五更, 每更约为两个小时。古人又把一天二十四小时划分为十二个 时辰, 用子、丑、寅、卯、辰、巳、午、未、申、西、戌、亥来表示。去年 
广受欢迎和好评的一部剧《长安十二时辰》描述的就是长安二十四个小时内 发生的一系列事情, 不少观众以为十二个时辰就是十二个小时。“三更” 指 得便是子时(23-1 时), “三更”之始是 23 时。“点” 就是更点, 是比 “更” 小的计时单位。“每一更又分为五点, 每点约为 24 分钟” (韦建中、黄兰, 1986）[8]。所以 “三更四点” 准确的时间应该是晚上 12 点 36 分, 我们现在 也有 “半夜三更” 的说法。杨宪益的译文中, 把 “三更四点” 直译成了 “the fourth stroke of the third watch”, 不但对原文理解不准确, 表达模糊, 译文 也给外国读者的理解带来了障碍, 读者不理解译文, 不可避免地就会对译文 内容进行猜测和想象。而在莱尔的译文中, 则采取了王建国提出的压缩策略, 使用了直译加注的方法, 注释“The time given is about midnight” 则给出了 “三 更四点” 准确和清晰的解释, 扫除了外国读者的理解障碍, 限定了他们的想 象空间。正如上文中所提到的那样, 汉英翻译中的 “压缩” 就是把汉语中模 糊的内容转化成相对精确的内容。

例 4: 老马兵为大家唱丧堂歌, 用个空的量米木升子, 当作小鼓, 把手 剥剥剥的一面敲着一面唱下去一一唱 “王祥卧冰” 的事情, 唱 “黄香扇枕” 的事情。(沈从文, 2017: 72) [9]

金介甫译: He sang songs about children who were legendary exemplars of filial piety: about Wang Xiang, who lay naked on top of ice to catch a fish for his mean stepmother, and little Huang Xiang, who fanned the pillow of his sick father against the heat and warmed him with his own body to ward off the cold. (Kinkley, 2009: 61) [10]

金隄译: While the others continued to watch over the coffin, in accordance with immemorial custom, singing songs and beating on a small drum made from an overturned rice-measure, singing the song "Wang Hsiang Lying on the Ice" and "Huang Hsiang Fanning the Pillow," both songs from the "Famous Twenty-four Filial Sons," an ancient Taoist book. (金隄, 1947: 60) [11]

“王祥卧冰” 和 “黄香扇枕” 也属于典型的文化负载词, 两者讲得均是 孝敬父母的故事。孝敬父母一直是中国伦理道德和核心规范之一, 同时也是 中国的传统美德。古代很多孝敬父母的佳话不仅感人至深, 而且流传甚广和 影响甚远。王祥和黄香的故事便是其中比较有名的故事。金介甫的译文中, 采取了压缩策略, 译文中不但解释了王祥和黄香是孝顺父母的模范人物, 还 详细阐述了 “王祥卧冰” 和 “黄香扇枕” 故事的具体内容, 把原文比较模糊 的内容转化成了相对精确的内容, 限制了读者的想象空间, 表现出很强的界 限意识。外国读者即使缺乏中国的相关文化背景知识, 也可以通过金介甫的 译文, 清晰地理解这两个故事。金隄的译文采取了直译的方法, 并且只交代 了王祥和黄香是二十四孝中的孝子。与金介甫的译文相比, 金隄的译文相对 比较模糊, 外国读者并不能从译文中清晰准确地了解 “王祥卧冰” 和 “黄香 扇枕” 的故事。

例 5: 又说: “只看二老今天那么一股劲儿, 就可以猜想得出这劲儿是 岸上一个黄花姑娘给他的！” (沈从文，2017：39) [9]

金介甫译: And, “Just from the spirit that No.2 showed in today's race, you 
could almost guess that he got it from a young maiden watching him from onshore." (Kinkley, 2009: 34) [10]

金隄译: .... and then she heard the other speaking in excited tones: "It is quite certain he is in love. There must be a yellow-flower maiden on shore who has given him all that courage.” (金隄: 1947: 33) [11]

“黄花姑娘” 也属于典型的社会文化负载词, 指得是未婚年轻的女子。 古代未出嫁的女子会用黄色的花粉调成粉料用来化妆, 《木兰辞》中也有诗 句: “当窗理云䰅, 对镜贴花黄”。后来便有人把 “花黄” 颠倒, 用在 “姑 娘”一词前面, 组成 “黄花姑娘”一词, 用来指没有结婚的年轻女性。金介 甫采用了压缩策略, 把 “黄花姑娘” 译成“young maiden”, 英文中的 “ maiden” 一词本来指得就是未婚女性, 再加上 “young” 这个修饰词, 金介甫对原文的 翻译非常准确和贴切, 有助于外国读者的理解。而金隄则将其直译成了 “yellow-flower maiden” , 英文中的 “yellow flower” 并没有承载特殊的文化 含义, 金隄的译文有很大可能会让外国读者感到迷茫和困惑, 影响其对原文 的理解。由此可见, 采用压缩策略翻译文化负载词, 更容易表达出原文的准 确意思和易于被外国读者理解。

例 6: 那二老说: “伯伯, 你到这里见过两万个日头, 别人家全说我们 这个地方风水好, 出大人, 不知为什么原因, 如今还不出大人? ” (沈从文, 2017: 32) [9]

金介甫译: At that, No. 2 said, “Uncle, you've seen a lot of sunrises in this locale. Everybody says the excellent feng shui here, the geomancy, is propitious for the emergence of great men. I wonder why we haven't had one so far?" (Kinkley, 2009: 28) [10]

金隄译: “Well, you've seen twenty thousand suns pass down the sky, and people say that the 'wind and water' signs are favourable here to the birth of a great man, but why is it that not a single great man has appeared?" (金隄, 1947: 27) [11]

“风水”一词属于典型的文化负载词, 金介甫的译文中采取了音译加增 添的方法。增添这一方法看似表面上使内容上得到了拓展, 实际上起了压缩 的功能, 厘清了概念的界限, 使界限变得更为明晰并具有排他性的功能。译 者把 “风水” 音译为 “feng shui”, 并增加了 “the geomancy”, 外国读者并 不熟悉 “feng shui” 这个概念, 通过添加 “the geomancy”, 使得这一概念的 边界得到压缩而至清晰, 限制了读者的想象空间。虽然 “风水” 和 “ the geomancy” 没办法完全等同, 但是译者已经尽可能排除了歧义, 给外国读者 提供了相对准确和清晰的译文。而金隄的译文中, 直接把 “feng shui”一词 译成了 “wind and water” signs”, 这一译文对于不熟悉中国文化的外国读者 来说, 很容易让其感到疑惑和费解, 并且加大了读者的想象空间, 译文内容 非常模糊, 表述不够清晰, 有歧义。通过金介甫和金隄译文的比较能够看出, 压缩策略在翻译文化负载词方面更加容易为外国读者所接受。

从上述分析中可以看出, 莱尔和金介甫作为母语为英语的译者, 翻译文 化负载词时使用了直译加注或者音译加注, 以及增添的翻译方法, 界限意识 
更强, 对文化负载词的翻译更加准确, 有助于外国读者的理解。这两位译者 对文化负载词的翻译体现出了压缩策略的翻译理念。与之相反, 杨宪益和金 隄作为母语皆为汉语的译者, 受到汉语界限不够清晰的影响, 两位译者对于 文化负载词的翻译不够准确, 加大了读者的想象空间, 引起歧义, 给外国读 者的理解带来了困难。

\section{4. 结语}

王建国曾经指出, 译者在翻译中不可避免地会受到母语的影响, 杨宪益 和金隄母语皆为汉语, 汉语是一门界限不够清晰的语言。因此杨宪益和金隄 的译本中对于文化负载词的翻译, 相较于莱尔和金介甫的翻译, 内容比较模 糊, 加大了读者的想象空间, 界限性不强, 容易产生歧义, 不利于外国读者 的理解。莱尔和金介甫母语皆为英语, 英语是一门界限清晰的语言。莱尔对 于《阿 $\mathrm{Q}$ 正传》中文化负载词的翻译, 采取压缩策略, 使用直译加注或者音 译加注的翻译方法, 金介甫对于《边城》中文化负载词的翻译也使用了压缩 策略, 多采取了增译的方法, 两位译者皆排除了文化负载词容易产生的歧义, 给读者提供了更精确的译文。尽管文化负载词的翻译比较困难, 压缩策略为 此类词的翻译提供了新的理论视角和解决方案。文化负载词对于翻译工作者 来说一直是个难题, 本文从压缩策略为文化负载词的翻译提供了一个新的角 度。但是因篇幅所限, 本文仅探讨了压缩策略在文化负载词中的应用, 没有 讨论压缩策略在汉语其他特殊语言现象中的应用, 后续的学者们可以从这个 角度开展研究。

\section{Conflicts of Interest}

The author declares no conflicts of interest regarding the publication of this paper.

\section{References}

[1] Nida, E.A. (2001) Language and Culture-Contexts in Translating. Shanghai Foreign Language Education Press, Shanghai.

[2] 包惠南, 包昂. 中国文化与汉英翻译[M]. 北京: 外文出版社, 2004: 10.

[3] 廖七一. 当代西方翻译理论探索 $[\mathrm{M}]$. 南京: 译林出版社, 2000.

[4] 王建国, 何自然. 重过程, 还是重结果一一译者的母语对英译文本的影响[J]. 上 海翻译, 2014(2): 7-12.

[5] 王建国. 汉英翻译学一一基础理论与实践 $[M]$. 北京: 中译出版社, 2019: 119.

[6] 鲁迅. 阿 Q 正传 $[\mathrm{M}]$. 杨宪益, 戴乃迭, 译. 北京: 外文出版社, 2016.

[7] Lyell, W.A., Trans. (1990) Diary of a Madman and Other Stories. University of Hawaii Press, Honolulu.

[8] 韦建中, 黄兰. “三更四点”究竟是什么时间? [J]. 语文学习, 1986(7): 14.

[9] 沈从文. 边城[M]. 北京: 中国文联出版社, 2017.

[10] Kinkley, J.C. (2009) The Border Town. Harper Collins Publishers, New York.

[11] 金隄, 白英 (1947) The Frontier City. Allen \& Unwin, London. 


\section{Appendix (Abstract and Keywords in Chinese)}

压缩策略下《阿 $\mathrm{Q}$ 正传》和《边城》两英译本中文化负载词的翻译对比研究

摘要: 文化负载词在翻译中非常重要, 可以促进跨文化交流。同时文化 负载词的翻译对于译者来说, 也存在不小的障碍。鲁迅的《阿 $\mathrm{Q}$ 正传》和沈 从文的《边城》这两部优秀的小说中都含有大量的文化负载词。杨宪益、戴 乃迭夫妇还有著名翻译家莱尔都曾把《阿 $\mathrm{Q}$ 正传》翻译成英文。金隄、白英 以及金介甫也把沈从文的《边城》翻译成了英文, 将其介绍给了外国观众。 针对汉英翻译, 王建国教授提出 “压缩策略”, 并认为这一策略是汉英翻译 的唯一策略, 这一策略同样也适用于文化负载词的翻译。“压缩” 的目的在 于减少歧义, 限制读者的想象空间, 给他们提供更加准确的理解。本文将结 合 “压缩策略” 翻译理论, 评析《阿 $\mathrm{Q}$ 正传》和《边城》两译本中对于文化 负载词的翻译。

关键词: 压缩策略, 文化负载词, 《阿 $\mathrm{Q}$ 正传》, 《边城》 